Zhenguo Liu, Yuehua Jiang, Hong Hao, Kalpna Gupta, Jian Xu, Ling Chu, Edward McFalls, Jay Zweier, Catherine Verfaillie and Robert J. Bache

Am J Physiol Heart Circ Physiol 293:1760-1765, 2007. First published Jun 1, 2007;

doi:10.1152/ajpheart.01408.2006

You might find this additional information useful...

This article cites 33 articles, 13 of which you can access free at:

http://ajpheart.physiology.org/cgi/content/full/293/3/H1760\#BIBL

This article has been cited by 2 other HighWire hosted articles:

Accumulation of VEGFR-2+/CD133+ cells and decreased number and impaired functionality of CD34+/VEGFR-2+ cells in patients with SLE

P. Ebner, F. Picard, J. Richter, E. Darrelmann, M. Schneider, B.-E. Strauer and M. Brehm

Rheumatology, January 1, 2010; 49 (1): 63-72.

[Abstract] [Full Text] [PDF]

eNOS Activation by Physical Forces: From Short-Term Regulation of Contraction to Chronic Remodeling of Cardiovascular Tissues

J.-L. Balligand, O. Feron and C. Dessy

Physiol Rev, April 1, 2009; 89 (2): 481-534.

[Abstract] [Full Text] [PDF]

Updated information and services including high-resolution figures, can be found at:

http://ajpheart.physiology.org/cgi/content/full/293/3/H1760

Additional material and information about AJP - Heart and Circulatory Physiology can be found at: http://www.the-aps.org/publications/ajpheart

This information is current as of August 12, 2010 .

AJP - Heart and Circulatory Physiology publishes original investigations on the physiology of the heart, blood vessels, and lymphatics, including experimental and theoretical studies of cardiovascular function at all levels of organization ranging from the intact animal to the cellular, subcellular, and molecular levels. It is published 12 times a year (monthly) by the American

Physiological Society, 9650 Rockville Pike, Bethesda MD 20814-3991. Copyright @ 2007 by the American Physiological Society. ISSN: 0363-6135, ESSN: 1522-1539. Visit our website at http://www.the-aps.org/. 


\title{
Endothelial nitric oxide synthase is dynamically expressed during bone marrow stem cell differentiation into endothelial cells
}

\author{
Zhenguo Liu, ${ }^{1}$ Yuehua Jiang, ${ }^{2}$ Hong Hao, ${ }^{1}$ Kalpna Gupta, ${ }^{3}$ Jian Xu, ${ }^{1}$ Ling Chu, ${ }^{1}$ Edward McFalls, ${ }^{4}$ \\ Jay Zweier, ${ }^{1}$ Catherine Verfaillie, ${ }^{2}$ and Robert J. Bache ${ }^{5}$ \\ ${ }^{1}$ Davis Heart and Lung Research Institute, The Ohio State University Medical Center, Columbus, Ohio; and ${ }^{2}$ Stem Cell \\ Institute, ${ }^{3}$ Division of Hematology, Oncology, and Transplantation, Department of Medicine, ${ }^{4}$ Division of Cardiology, \\ Minneapolis Veterans Affairs Medical Center, and ${ }^{5}$ Division of Cardiovascular Diseases, Department of Medicine, University \\ of Minnesota Medical School, Minneapolis, Minnesota
}

Submitted 22 December 2006; accepted in final form 30 May 2007

Liu Z, Jiang Y, Hao H, Gupta K, Xu J, Chu L, McFalls E, Zweier J, Verfaillie C, Bache RJ. Endothelial nitric oxide synthase is dynamically expressed during bone marrow stem cell differentiation into endothelial cells. Am J Physiol Heart Circ Physiol 293: H1760-H1765, 2007. First published June 1, 2007; doi:10.1152/ajpheart.01408.2006.-This study was designed to investigate the developmental expression of endothelial nitric oxide synthase (eNOS) during stem cell differentiation into endothelial cells and to examine the functional status of the newly differentiated endothelial cells. Mouse adult multipotent progenitor cells (MAPCs) were used as the source of stem cells and were induced to differentiate into endothelial cells with vascular endothelial growth factor (VEGF) in serum-free medium. Expression of eNOS in the cells during differentiation was evaluated with real-time PCR, nitric oxide synthase (NOS) activity, and Western blot analysis. It was found that eNOS, but no other NOS, was present in undifferentiated MAPCs. eNOS expression disappeared in the cells immediately after induction of differentiation. However, eNOS expression reoccurred at day 7 during differentiation. Increasing eNOS mRNA, protein content, and activity were observed in the cells at days 14 and 21 during differentiation. The differentiated endothelial cells formed dense capillary networks on growth factor-reduced Matrigel. VEGF-stimulated phosphorylation of extracellular signal-regulated kinase (ERK)-1 and ERK-2 occurred in these cells, which was inhibited by NOS inhibitor $N^{\mathrm{G}}$-nitro-L-arginine methyl ester. In conclusion, these data demonstrate that eNOS is present in MAPCs and is dynamically expressed during the differentiation of MAPCs into endothelial cells in vitro.

progenitor cells

NITRIC OXIDE (NO) is a highly reactive small molecule that is involved in a wide range of biological events in almost all living systems (22). NO is generated from L-arginine by NO synthase (NOS) with the formation of L-citrulline (23). The regulation and modification of $\mathrm{NO}$ production is a key step in the control of many biological processes in both physiological and pathophysiological conditions. Many growth factors, pharmacological agents, and environmental factors can contribute to the regulation of the function and expression of NOS (10).

Three different isoforms of NOS have been identified, including neuronal NOS (nNOS or NOS-I), inducible NOS (iNOS or NOS-II), and endothelial NOS (eNOS or NOS-III) (2). eNOS is a $133-\mathrm{kDa}$ protein with 1,203 amino acids that was identified initially in vascular endothelial cells. It plays a

Address for reprint requests and other correspondence: Z. Liu, Davis Heart \& Lung Research Inst., The Ohio State Univ. Medical Ctr., Rm. 260 DHLRI, 473 W. 12th Ave., Columbus, OH 43210 (e-mail: zhenguo.liu@osumc.edu). critical role in the functioning of endothelial cells. eNOS is essential in the signaling for vascular endothelial growth factor (VEGF), which is required for the development and function of endothelial cells $(8,11)$. eNOS contributes importantly to the endothelium-dependent vascular functions, including vasodilation and angiogenesis. Recent evidence indicates that mobilization of endothelial progenitor cells is dependent on eNOS (1), suggesting that eNOS-dependent mobilization of stem cells and endothelial progenitor cells may have a potential therapeutic role in ischemic heart disease and tissue repair. Therefore, understanding the natural course of eNOS expression during endothelial cell differentiation and development may help to characterize the mechanisms by which NO influences endothelial cell development and function.

Reyes et al. $(26,27)$ recently purified, cultured, and characterized bone-marrow multipotent adult progenitor cells (MAPCs) from both human and mouse. These cells were $\mathrm{CD}_{4}{ }^{-}, \mathrm{CD} 45^{-}, \mathrm{c}^{-\mathrm{kit}^{-}}$, and sca- ${ }^{+}$and were able to differentiate into multiple cell lineages in vitro, including endothelial cells. These endothelial cells derived from MAPCs not only express endothelial markers like von Willebrand factor (vWF) but also display the full range of endothelial functions including LDL uptake, secretion of VEGF, vascular tube formation, and in vivo neoangiogenesis in tumors and wound healing. During the in vitro differentiation of MAPCs to endothelial cells, the stages of cell differentiation from the progenitor cells can be easily defined. The aim of this study, using this in vitro system, was to investigate the pattern of eNOS expression during the course of stem cell differentiation into endothelial cells and to examine the functional status of the newly differentiated endothelial cells.

\section{MATERIALS AND METHODS}

Stem cell culture and differentiation into endothelial cells. Mouse MAPCs were cultured in expansion medium in culture flasks coated with $5 \mathrm{ng} / \mathrm{ml}$ of fibronectin (FN, Sigma) at $37^{\circ} \mathrm{C}$ with $95 \% \quad \mathrm{O}_{2}-5 \%$ $\mathrm{CO}_{2}$ as previously described (17) and maintained at cell densities between 2 and $5 \times 10^{3}$ cells $/ \mathrm{cm}^{2}$ by sequential subculture. To induce differentiation to endothelial cells, MAPCs were replated at $2 \times 10^{4}$ cells $/ \mathrm{cm}^{2}$ in $\mathrm{FN}$-coated culture vessels or chamber slides at $37^{\circ} \mathrm{C}$ with $95 \% \mathrm{O}_{2}-5 \% \mathrm{CO}_{2}$ in serum-free culture media in the presence of 10 $\mathrm{ng} / \mathrm{ml}$ VEGF (R\&D Systems) as described previously in detail (17, 26,27 ). Cultures were maintained by media exchange every 3 days. In

The costs of publication of this article were defrayed in part by the payment of page charges. The article must therefore be hereby marked "advertisement" in accordance with 18 U.S.C. Section 1734 solely to indicate this fact. 
some instances, cells were subcultured after day 9 of differentiation at a 1:4 dilution under the same culture conditions. The cells were collected at days $0,1,3,5,7,10,14,21,28$, and 35 of culture for immunostaining of endothelial marker vWF and eNOS or Western blot analysis for eNOS and eNOS activity determination.

Immunofluorescence staining for $v W F$. Undifferentiated MAPCs or MAPCs induced to differentiate into endothelial cells plated in FNcoated chamber slides at days 1, 3, 5, 7, 10, 14, and 21 were fixed with $2 \%$ paraformaldehyde (Sigma) for $4 \mathrm{~min}$ at room temperature. The cells were further prepared for immunofluorescence staining for vWF as described previously in detail $(17,18)$. The dilution factor for primary antibodies (Abs) against vWF (Santa Cruz) was 1:100. The dilution factor for secondary Abs (anti-goat IgG-Cy-3; Sigma) was 1:200. Slides exposed to the secondary Abs only were used as negative controls, and cultured human umbilical vein endothelial cells (HUVECs) were used as a positive control.

Assessment of eNOS expression during differentiation. Western blot analysis of eNOS protein was carried out to quantitatively determine the expression of eNOS during the course of MAPC differentiation. MAPCs and day-1, -3, -5, -7, -10, -14, -21, -28, and -35 differentiated progeny were collected in the form of a pellet by centrifugation at $1,600 \mathrm{rpm}$ for $5 \mathrm{~min}$ at $4^{\circ} \mathrm{C}$ and frozen at $-80^{\circ} \mathrm{C}$ until analysis. Immunoblotting was conducted as previously described with minor modifications (29). The dilution factor for primary $\mathrm{Ab}$ against eNOS (Santa Cruz) was 1:1,500, whereas the dilution factor for secondary $\mathrm{Ab}$ conjugated with horseradish peroxidase (Sigma) was 1:2,000. HUVEC protein was used as a positive control.

NOS catalytic activity assay. The conversion of $\mathrm{L}-\left[{ }^{14} \mathrm{C}\right] \operatorname{arginine}$ to $\mathrm{L}-\left[{ }^{14} \mathrm{C}\right]$ citrulline was used to determine the catalytic activity of NOS as described previously with minor modifications (12). The radioactivity of the samples was counted in a Beckman LS 3801 scintillation counter. The enzymatic activity was expressed as picomoles of L-citrulline per milligrams protein per minute. To determine $\mathrm{Ca}^{2+}$ dependent NOS activity, $\mathrm{Ca}^{2+}$ was omitted from the assay solution and $2 \mathrm{mM}$ EDTA was added to remove any remaining $\mathrm{Ca}^{2+}$ in the incubation system. NOS activity from HUVEC protein was used as a positive control.

Quantitative real-time PCR for eNOS $m R N A$. Quantitative realtime PCR assay was used to assess eNOS mRNA levels during MAPC differentiation into endothelial cells with the method described in detail previously (18). The primer sequence used for eNOS was CACCAGGAAGAAGACCTTTAAGGA (forward) and CACACGCTTCGCCATCAC (reverse). The mRNA levels were normalized by using GAPDH as a housekeeping gene (forward: CCAATCAGCTTGGGCTAGAG; reverse: CCTGGGAAAGGTGTCCTGTA) and compared with levels in the mouse universal gene.

In vitro tube formation assay. In vitro vascular tube formation from the cells differentiated from MAPCs was evaluated in three-dimensional cultures with growth factor-reduced Matrigel $(10 \mathrm{mg} / \mathrm{ml}$; Collaborative Research, Bedford, MA) as described previously (14). We seeded MAPC-derived endothelial cells $\left(5 \times 10^{4}\right)$ in serum-free and growth factor-free medium on the surface of the Matrigel previously polymerized overnight. Cultures were incubated with or without VEGF $(10 \mathrm{ng} / \mathrm{ml})$ at $37^{\circ} \mathrm{C}$ and observed for tube formation every hour. Human dermal microvascular endothelial cells (MECs) and fibroblasts were used as positive and negative controls.

Phosphorylation studies. In vitro VEGF-stimulated phosphorylation of extracellular signal-regulated kinase (ERK)-1 [p44 mitogenactivated protein kinase (p44 MAPK)] and ERK-2 (p42 MAPK), and the serine/threonine protein kinase Akt (protein kinase B) were analyzed as described previously $(11,14)$. Briefly, subconfluent cultures of cells differentiated from MAPCs and human dermal MECs were incubated in serum-free medium overnight at $37^{\circ} \mathrm{C}$. The cells were stimulated with VEGF for different times at different concentrations. To evaluate the effect of NO on the VEGF-stimulated phosphorylation, a group of cells was pretreated with $100 \mu \mathrm{M} N^{\mathrm{G}}$-nitro-L-arginine methyl ester (L-NAME) for $5 \mathrm{~min}$ before the addition of VEGF.
Whole cell lysates (30 $\mu \mathrm{g}$ protein) resolved on $10 \%$ SDS-PAGE were transferred to a polyvinylidene difluoride membrane (Immobilon; Millipore, Bedford, MA). Immunoblotting was performed using antibodies to phospho-p44/42 MAPK/ERK (Thr202/Tyr204), total MAPK/ERK, phospho-Akt, and total Akt (New England Biolabs, Beverly, MA). The immunoreactive proteins were visualized with ECF Western blotting system (Amersham Life Sciences, Buckinghamshire, UK), and chemiluminescent signals were acquired using Storm 860 Phosphorimager (Molecular Dynamics, Sunnyvale, CA) as described previously (15).

Statistical analysis. The data were expressed as means \pm SD for all experimental measurements. Statistical analysis was done using one-way ANOVA, and statistical significance was determined as $P<0.05$.

\section{RESULTS}

Differentiation of MAPCs into endothelial cells in vitro. The phenotype and multilineage differentiation potential (i.e., meosodermal, endodermal, and ectodermal capacity) of MAPCs used in this study were routinely checked monthly for quality control. To ensure that MAPCs differentiated into endothelial cells in this controlled culture system, the appearance of the endothelial marker vWF was evaluated throughout the course of differentiation. The cells first became vWF positive on day 10 during the course of differentiation as shown in Fig. 1, $A$ and $B$, which was consistent with previous observations $(17,18,26,27)$.

NOS expression in the cells at different stages of differentiation. As shown in Fig. $2 A, \mathrm{Ca}^{2+}$-dependent NOS activity was observed in MAPCs before the initiation of cell differentiation with an activity equivalent to $\sim 25 \%$ of NOS activity in HUVECs. No $\mathrm{Ca}^{2+}$-independent NOS activity was observed in these cell preparations. NOS activity was lost at the beginning of differentiation (day 1) and remained absent throughout in the first week. However, measurable $\mathrm{Ca}^{2+}$-dependent NOS activity reappeared in the cells after $1 \mathrm{wk}$ of differentiation and increased by weeks 2 and 3. After week 3, NOS activity tended to decline, although this was not statistically significant $(P>$ $0.05)$. No $\mathrm{Ca}^{2+}$-independent NOS activity was detected in the cells at any stage of differentiation (data not shown).

Western blot analysis, as shown in Fig. 2B, demonstrated that eNOS, but no iNOS (not shown), was present in MAPCs before differentiation. No eNOS expression was detected in the first week of differentiation. However, expression of eNOS reappeared in the cells after $1 \mathrm{wk}$ of differentiation, and the level of expression increased over time with the highest level detected at week 3. Quantitative real-time PCR revealed a similar pattern of eNOS expression in the cells during differentiation as shown in Fig. 2C. No iNOS was expressed at any time during cell differentiation (data not shown).

Vascular tube formation. Endothelial cells differentiated from MAPCs at weeks 2 and 3 were evaluated for tube formation in vitro on growth factor-reduced Matrigel. As shown in Fig. 3, the newly differentiated cells formed dense networks of branching and anastomosing cords on the Matrigel. The cells also formed tubes on the Matrigel without the addition of VEGF (data not shown). The number of branches and the length of the tubes formed by MAPC-derived endothelial cells were much greater than those formed by MECs (Fig. 3, $B$ and $C$ ). The tube formation potential by the differentiated cells, as assessed by the number of branches and the length of the tubes, tended to decrease after week 3 (Fig. 3D). 
A

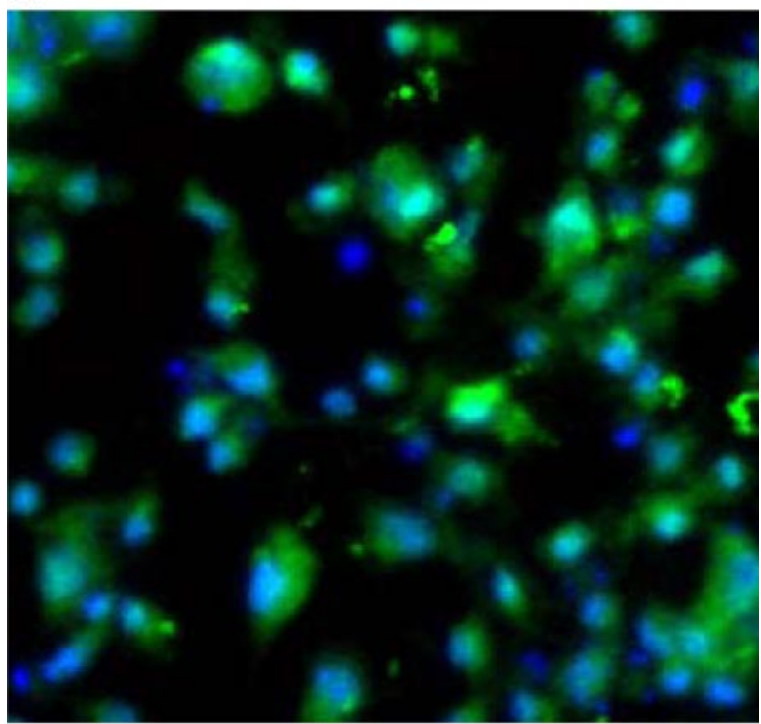

B

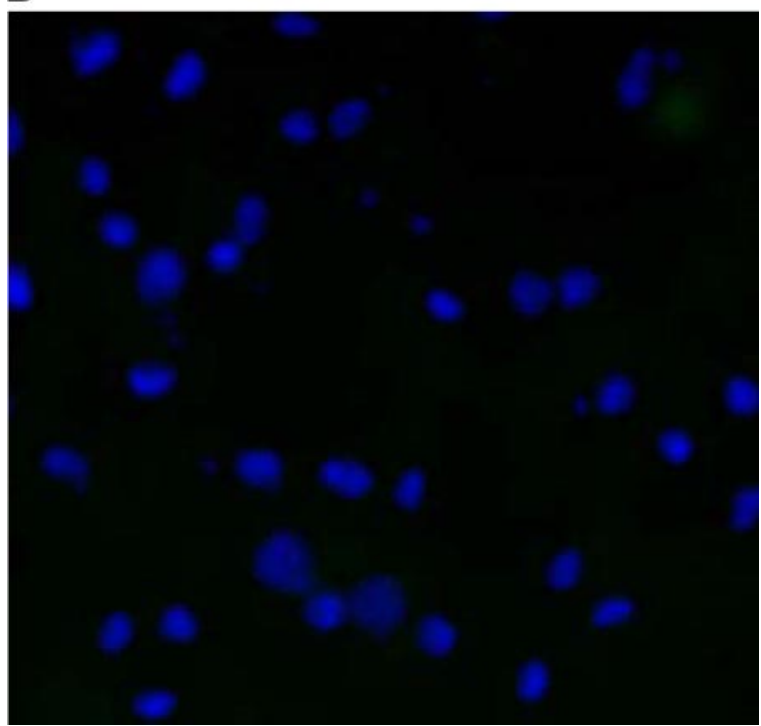

Fig. 1. Immunofluorescence staining for von Willebrand factor (vWF) (magnification, $\times 200$ for $A$ and $B$ ). A: newly differentiated endothelial cells from bone-marrow stem cells were stained positive for vWF at week 2 after the initiation of differentiation in serum-free medium in the presence of VEGF. $B$ : control staining.

In vitro phosphorylation of p42/44 MAPK/ERK. Western blot analysis, as shown in Fig. 4, $A$ and $B$, demonstrated that VEGF stimulated MAPK/ERK phosphorylation in a time- and concentration-dependent manner. VEGF-induced P42/44 MAPK/ERK phosphorylation started to occur $5 \mathrm{~min}$ after exposure to VEGF in the cells at the stage of week 2 of differentiation. The maximal phosphorylation of both p42 and p44 forms of MAPK was achieved by 15 min of treatment with VEGF (Fig. 4A). Both p42 and p44 protein kinases were maximally phosphorylated at a concentration of $2.0 \mathrm{ng} / \mathrm{ml}$ of VEGF (Fig. 4B). Pretreatment of the cells with the NOS inhibitor L-NAME reduced VEGF-stimulated MAPK/ERK phosphorylation. The phosphorylation levels of the protein kinases were decreased when the concentration of VEGF was over $100 \mathrm{ng} / \mathrm{ml}$ (data not shown).

\section{DISCUSSION}

In the present study we demonstrated for the first time that eNOS was dynamically expressed during the course of MAPC differentiation into endothelial cells in vitro. Using a similar preparation, Reyes et al. (27) and Jiang et al. $(17,18)$ showed that the endothelial cell-specific markers vascular endothelial cadherin and receptor tyrosine kinase (Tek) were expressed as early as day 3 after the initiation of differentiation of MAPCs, whereas the more mature marker $\mathrm{vWF}$ was expressed from day 9. The appearance of vWF was associated with the ability
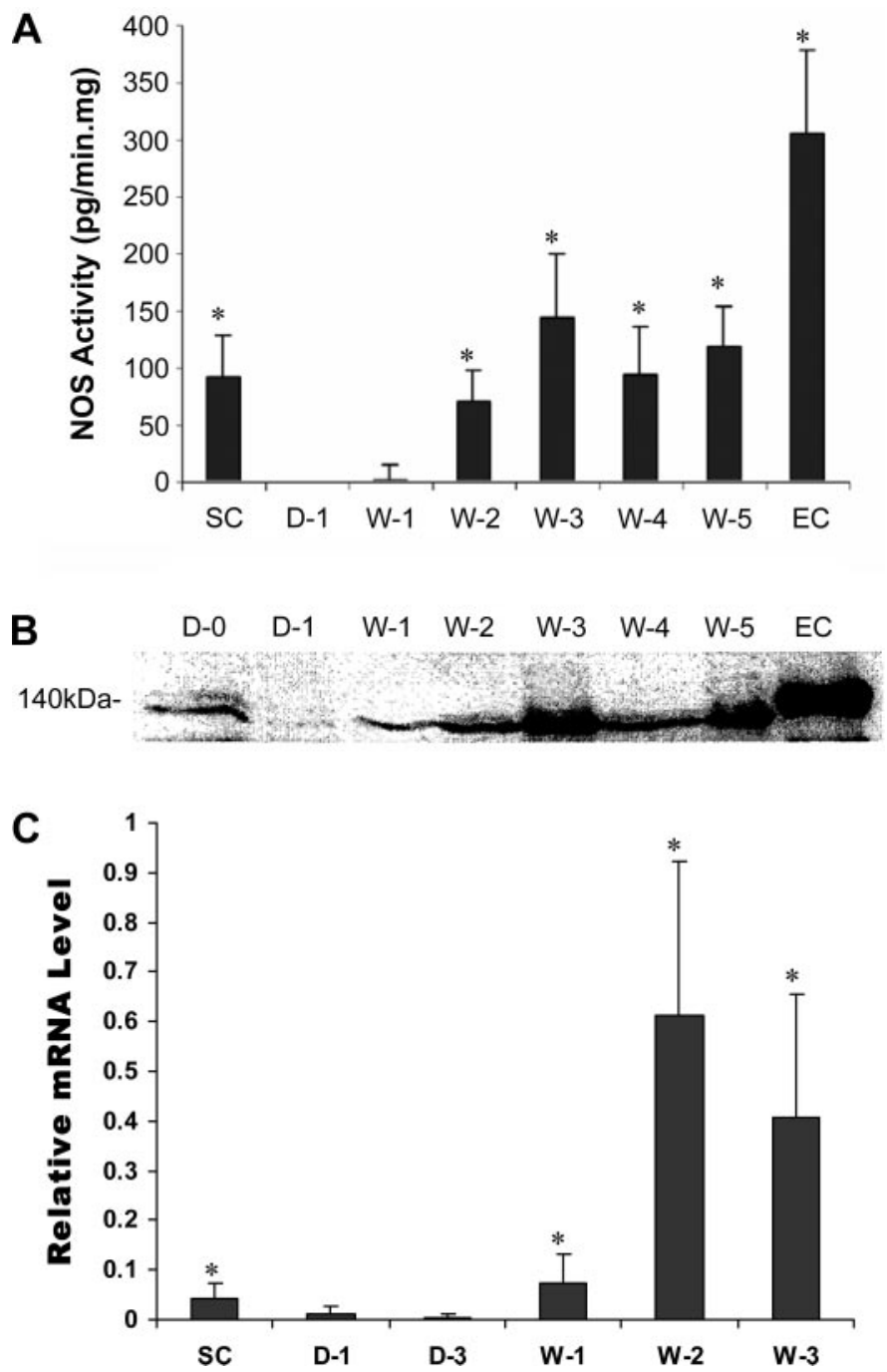

Fig. 2. Endothelial nitric oxide synthase (eNOS) expression during the course of bone-marrow stem cell differentiation into endothelial cells. $* P<0.05$ compared with day 1. A: eNOS activity in the cells during the course of differentiation. Both $\mathrm{Ca}^{2+}$-dependent and -independent nitric oxide synthase (NOS) activity was measured using the conversion of L-arginine to L-citrulline method as detailed in MATERIALS AND METHODS. The data were expressed as means $\pm \mathrm{SD}$ ( $n=3$ experiments). $B$ : eNOS expression in the differentiating cells by Western immunoblot analysis. Cells were collected at different stages of differentiation. Cell lysates were prepared for Western immunoblot analysis as detailed in MATERIALS AND METHODS. $C$ : eNOS mRNA levels in the cells during the course of differentiation of bone-marrow stem cells into endothelial cells. The data were expressed as means $\pm \mathrm{SD}(n=3$ experiments). SC, undifferentiated bone marrow stem cell [day 0 (D-0)]; EC, human umbilical vein endothelial cells; D-1 to -3 , days 1 to 3 of cell differentiation; W- 1 to -5 , weeks 1 to 5 of cell differentiation. 
A

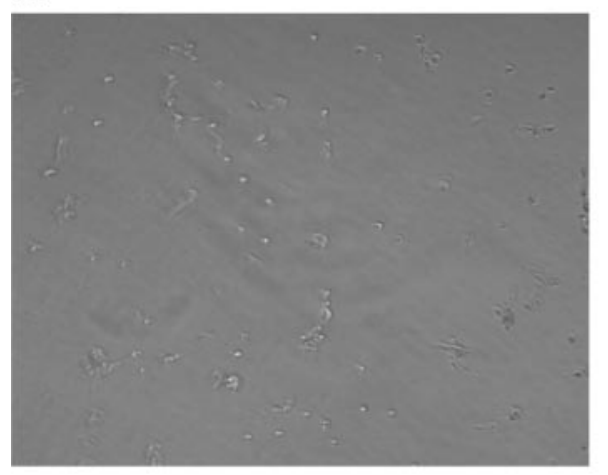

C

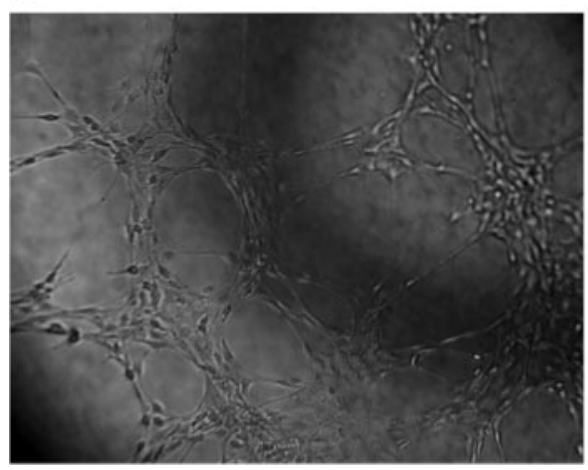

B

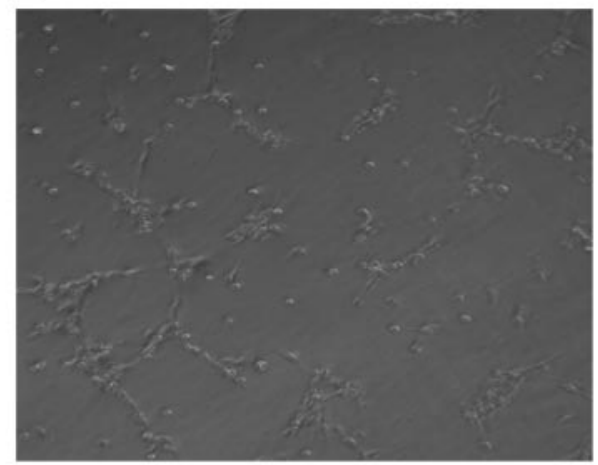

D

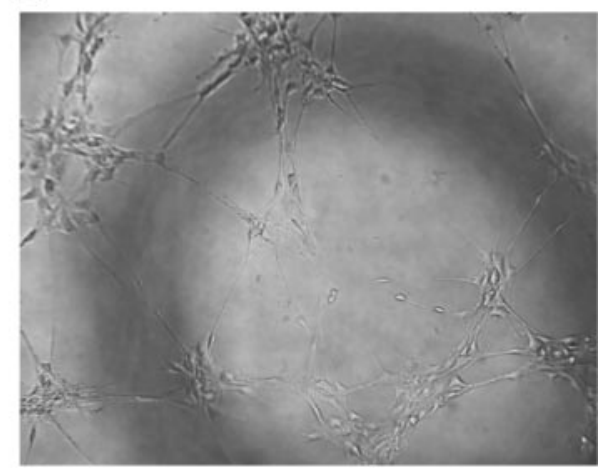

Fig. 3. Tube formation by differentiated cells from stem cells on growth factor-reduced Matrigel. The cells at different stages of differentiation were plated on growth factor-reduced Matrigel for in vitro vascular tube formation as detailed in MATERIALS AND METHODS. Human dermal microcirculatory endothelial cells (MECs) and fibroblast cells were used as a positive and negative control. $A$ : fibroblast control. $B$ : tube formation by MECs. $C$ : tube formation by the newly differentiated endothelial cells at week 2 of differentiation. $D$ : tube formation by the newly differentiated endothelial cells at week 3 of differentiation.

of differentiated endothelial cells to uptake acetylated lowdensity lipoprotein (aLDL), indicative of the beginning of endothelial cell function. In the present study, vWF was expressed in the cells on day 10, which was consistent with the above observations, assuring that the cells were indeed differentiating into endothelial cells. However, it was not clear at this point that these cells were endothelial progenitor cells or mature endothelial cells. Therefore, it might be more appropriate to call these cells endothelial-like cells.

A

Phosph MAPK

Total MAPK

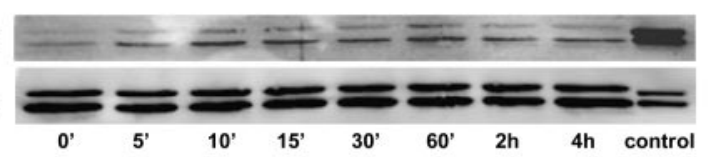

B

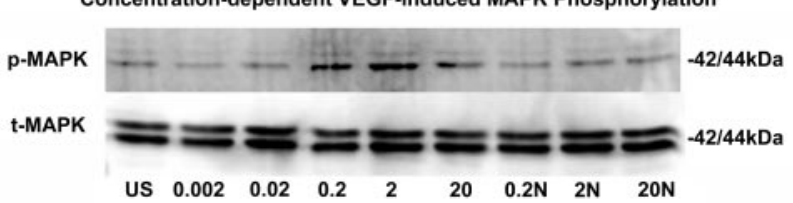

Fig. 4. Phosphorylation (p) of p42 and p44 MAPK by VEGF in the differentiated endothelial cells from bone-marrow stem cells. $A$ : phosphorylation of p42 and p44 MAPK by VEGF in the newly differentiated endothelial cells in a time-dependent manner at week 2 of differentiation. B, left: dose-dependent phosphorylation of p42 and p44 MAPK by VEGF $(0.001-10 \mathrm{ng} / \mathrm{ml})$ in the cells at week 2 of differentiation. B, right: effect of $N^{\mathrm{G}}$-nitro-L-arginine methyl ester on VEGF-stimulated phosphorylation of ERK1 (p44 MAPK) and ERK2 (p42 MAPK) in these cells at week 2 of differentiation. The MAPK phosphorylation was significantly decreased by treatment with $100 \mu \mathrm{M}$ L-NAME as labeled with N. The unstimulated (US) group (control) is considered as background.
There were some data available in the literature concerning the developmental expression of NOS during embryogenesis. Wildemann and Bicker (31) reported that NOS in Drosophila embryos (dNOS) was first expressed when the embryos passed stage 15. Bloch et al. (4) showed that no NOS was detected in the first 7.5 days of both murine and rat embryonic development. However, beginning from day 9.5 of embryonic development, both iNOS and eNOS were expressed. The expressions of both iNOS and eNOS were decreased after day 14.5; iNOS became almost undetectable shortly before birth, whereas eNOS expression was downregulated to low levels. Sheppard et al. (29) observed that the expression of eNOS protein in the placental artery of pregnant ewes peaked at 130 days of gestation and then returned to baseline levels at 142 days of pregnancy. In the present study, eNOS expression was also dynamic during the course of differentiation with maximal levels at week 3 . This changing pattern of expression likely reflected a dynamic regulatory mechanism of the enzyme.

An important function of endothelial cells was the formation of new vasculature (angiogenesis) in the presence of VEGF. NO was involved in angiogenesis via MAPK activation and fibroblast growth factor expression (32). VEGF was critical to the differentiation and proliferation of endothelial cells, and NO functioned as an important effector of the biological actions of VEGF $(9,24,28,33)$. The serine/threonine kinase Akt was crucial to VEGF-induced angiogenesis signaling (30). eNOS was activated through direct phosphorylation by Akt, linking the signal transduction from VEGF to the release of NO in endothelial cells $(5,11)$. In the present study, the endothelial cells differentiated from MAPCs formed vascular tube networks on Matrigel. In addition, the MAPK was phosphorylated 
in endothelial progeny in response to VEGF stimulation in a time- and concentration-dependent manner. These data indicated that the VEGF-Akt-eNOS-MAPK signal transduction pathway was well established in these cells. Further in vivo studies to demonstrate the involvement of these newly differentiated endothelial cells in the process of reendothelialization or repair of injured vasculature could represent a significant therapeutic value for these cells.

One of the interesting findings in the present study was that eNOS was present in the undifferentiated MAPCs. One might argue that this was due to a fraction of already differentiated vasculogenic progenitors in the MAPCs. It is high unlikely. The undifferentiated MAPCs had unique morphology and biological markers without expression of vWF. As mentioned in RESULTS, the cell quality including phenotype was checked regularly before differentiation. Previous studies demonstrated that isoforms of NOS existed in other stem/progenitor cells and played an important role in the function of these cells. Both eNOS and nNOS were detected in mouse neural progenitor cells $(21,30)$. It was also found that eNOS and iNOS were expressed in the cytoplasma of mouse oocytes and embryos during the preimplantation period (25). NOS activity decreased in embryos from the four-cell to the eight-cell stage during development. And in vitro embryo development was arrested at the two-cell stage when the one-cell embryos were exposed to the NOS inhibitor L-NAME; the developmental arrest was reversed by the addition of L-arginine (25). Inhibition of NOS activity in the imaginal discs of Drosophila larvae led to hypertrophy of tissues and organs of the adult fly (7). The eNOS-deficient mice exhibited significant limb reduction defects, profound bone formation abnormalities with decreased bone density, and increased neonatal loss as well as fetal growth restriction $(3,13,16)$. Compensatory lung growth was found to be severely impaired in eNOS-deficient mice (20). Very recently, Krumenacker et al. (19) demonstrated that nNOS and eNOS were present in the undifferentiated mouse embryonic stem cells. When the embryonic stem cells were induced to differentiate, nNOS expression quickly decreased within 1 day, whereas eNOS and iNOS expression increased significantly after 5 days. They also found that cGMP-mediated NO signaling might play a role in the early differentiation of murine embryonic stem cells into cardiomyocytes (19). These data implied that $\mathrm{NO}$ was involved in the proliferation and differentiation of stem cells at multiple stages of commitment in different species.

The finding that eNOS expression in MAPCs was turned off at the very beginning of differentiation suggested that NO might be important for maintaining the characteristics of stem cells. Our ongoing studies would soon determine the fate of MAPCs when cultured in the presence of NOS inhibitors to further address this hypothesis. The reappearance of eNOS expression later in the course of differentiation was likely a result of the transformation into endothelial cells and was essential for the full function of the differentiating cells. The dynamic nature of eNOS expression also suggested that NO might play different roles in the cells at different stage of differentiation and development. Further studies were needed to investigate the mechanisms for the alteration in eNOS expression during the course of differentiation.

In conclusion, eNOS was expressed in MAPCs, became downregulated during the induction of differentiation with
VEGF, and was again expressed as the cells acquired endothelial cell markers and function. The data suggest that NO may be important to maintain bone-marrow stem cells in the undifferentiated state before stimulation with VEGF, whereas the reexpression of eNOS appears to confer functional integrity to the differentiated endothelial cells.

\section{ACKNOWLEDGMENTS}

The data of this study were partially presented in 2002 American Heart Association Melvin L. Marcus Young Investigator Awards in Cardiovascular Science. We express great appreciation to Joseph Sikora and Rong Lou for technical support.

\section{GRANTS}

This study was supported by National Heart, Lung, and Blood Institute (NHLBI) Grants HL-21872, HL-20598, HL-68802, a research fellowship from the Lillehei Heart Institute at the University of Minnesota Medical School (to Z. Liu), and a NHLBI K08 Award HL-75410 (to Z. Liu).

\section{REFERENCES}

1. Aicher A, Heeschen C, Mildner-Rihm C, Urbich C, Ihling C, Technau-Ihling $\mathbf{K}$, Zeiher AM, Dimmeler S. Essential role of endothelial nitric oxide synthase for mobilization of stem and progenitor cells. Nat Med 9: 1370-1376, 2003

2. Alderton WK, Cooper CE, Knowles RG. Nitric oxide synthases: structure, function and inhibition. Biochem J 357: 593-615, 2001.

3. Armour KE, Armour KJ, Gallagher ME, Godecke A, Helfrich MH, Reid DM, Ralston SH. Defective bone formation and anabolic response to exogenous estrogen in mice with targeted disruption of endothelial nitric oxide synthase. Endocrinology 142: 760-766, 2001.

4. Bloch W, Fleischmann BK, Lorke DE, Andressen C, Hops B, Hescheler J, Addicks K. Nitric oxide synthase expression and role during cardiomyogenesis. Cardiovasc Res 43: 675-684, 1999.

5. Dimmeler S, Fleming I, Fisslthaler B, Hermann C, Busse R, Zeiher AM. Activation of nitric oxide synthase in endothelial cells by Aktdependent phosphorylation. Nature 399: 601-605, 1999.

6. Dimmeler S, Zeiher AM. Akt takes center stage in angiogenesis signaling. Circ Res 86: 4-5, 2000.

7. Enikolopov G, Banerji J, Kuzin B. Nitric oxide and Drosophila development. Cell Death Differ 6: 956-963, 1999.

8. Fleming I, Busse R. Signal transduction of eNOS activation. Cardiovasc Res 43: 532-541, 1999.

9. Fong GH, Rossant J, Gertsenstein M, Breitman ML. Role of the Flt-1 receptor tyrosine kinase in regulating the assembly of vascular endothelium. Nature 376: 66-70, 1995.

10. Forstermann U, Gath I, Schwarz P, Closs EI, Kleinert H. Isoforms of nitric oxide synthase. Properties, cellular distribution and expressional control. Biochem Pharmacol 50: 1321-1332, 1995.

11. Fulton D, Gratton JP, McCabe TJ, Fontana J, Fujio Y, Walsh K, Franke TF, Papapetropoulos A, Sessa WC. Regulation of endotheliumderived nitric oxide production by the protein kinase Akt. Nature 399: 597-601, 1999.

12. Garcia-Cardena G, Fan R, Stern DF, Liu J, Sessa WC. Endothelial nitric oxide synthase is regulated by tyrosine phosphorylation and interacts with caveolin-1. J Biol Chem 271: 27237-27240, 1996.

13. Gregg AR, Schauer A, Shi O, Liu Z, Lee CG, O'Brien WE. Limb reduction defects in endothelial nitric oxide synthase-deficient mice. Am J Physiol Heart Circ Physiol 275: H2319-H2324, 1998.

14. Gupta K, Kshirsagar S, Li W, Gui L, Ramakrishnan S, Gupta P, Law PY, Hebbel RP. VEGF prevents apoptosis of human microvascular endothelial cells via opposing effects on MAPK/ERK and SAPK/JNK signaling. Exp Cell Res 247: 495-504, 1999.

15. Gupta K, Kshirsagar S, Chang L, Schwartz R, Law PY, Yee D, Hebbel RP. Morphine stimulates angiogenesis by activating proangiogenic and survival-promoting signaling and promotes breast tumor growth. Cancer Res 62: 4491-4498, 2002.

16. Hefler LA, Reyes CA, O'Brien WE, Gregg AR. Perinatal development of endothelial nitric oxide synthase-deficient mice. Biol Reprod 64: 666$673,2001$.

17. Jiang Y, Jahagirdar BN, Reinhardt RL, Schwartz RE, Keene CD, Otiz X, Reyes M, Lenvik T, Lund T, Blackstad M, Du J, Aldrich S, 
Lisberg A, Low W, Largaespada D, Verfaillie CM. Pluripotency of mesenchymal stem cells derived from adult marrow. Nature 418: 41-49, 2002.

18. Jiang Y, Vaessen B, Lenvik T, Blackstad M, Reyes M, Verfaillie CM. Multipotent progenitor cells can be isolated from postnatal murine bone marrow, muscle, and brain. Exp Hematol 30: 896-904, 2002.

19. Krumenacker JS, Katsuki S, Kots A, Murad F. Differential expression of genes involved in cGMP-dependent nitric oxide signaling in murine embryonic stem (ES) cells and ES cell-derived cardiomyocytes. Nitric Oxide 14: 1-11, 2006.

20. Leuwerke SM, Kaza AK, Tribble CG, Kron IL, Laubach VE. Inhibition of compensatory lung growth in endothelial nitric oxide synthasedeficient mice. Am J Physiol Lung Cell Mol Physiol 282: L1272-L1278, 2002.

21. Micci MA, Learish RD, Li H, Abraham BP, Pasricha PJ. Neural stem cells express RET, produce nitric oxide, and survive transplantation in the gastrointestinal tract. Gastroenterology 121: 757-766, 2001.

22. Moncada S, Higgs A. The L-arginine-nitric oxide pathway. $N$ Engl J Med 329: 2002-2012, 1993.

23. Moncada S, Palmer RM, Higgs EA. Nitric oxide: physiology, pathophysiology, and pharmacology. Pharmacol Rev 43: 109-142, 1999.

24. Murohara T, Asahara T, Silver M, Bauters C, Masuda H, Kalka C, Kearney M, Chen D, Symes JF, Fishman MC, Huang PL, Isner JM. Nitric oxide synthase modulates angiogenesis in response to tissue ischemia. J Clin Invest 101: 2567-2578, 1998.
25. Nishikimi A, Matsukawa T, Hoshino K, Ikeda S, Kira Y, Sato EF, Inoue M, Yamada M. Localization of nitric oxide synthase activity in unfertilized oocytes and fertilized embryos during preimplantation development in mice. Reproduction 122: 957-963, 2001.

26. Reyes M, Dudek A, Jahagirdar B, Koodie L, Verfaillie CM. Origin of endothelial progenitors in human post-natal bone marrow. J Clin Invest 109: 337-346, 2002.

27. Reyes M, Lund T, Lenvik T, Aguiar D, Koodie L, Verfaillie CM. Purification and ex vivo expansion of postnatal human marrow mesodermal progenitor cells. Blood 98: 2615-2625, 2001.

28. Risau W. Mechanisms of angiogenesis. Nature 386: 671-674, 1997.

29. Sheppard C, Shaw CE, Li Y, Bird IM, Magness RR. Endotheliumderived nitric oxide synthase protein expression in ovine placental arteries. Biol Reprod 64: 1494-1499, 2001.

30. Wang T, FitzGerald TJ, Haregewoin A. Differential expression of nitric oxide synthases in EGF-responsive mouse neural precursor cells. Cell Tissue Res 296: 489-497, 1999.

31. Wildemann B, Bicker G. Developmental expression of nitric oxide/cyclic GMP synthesizing cells in the nervous system of Drosophila melanogaster. J Neurobiol 38: 1-15, 1999.

32. Ziche M, Morbidelli L. Nitric oxide and angiogenesis. J Neurooncol 50: 139-148, 2000.

33. Ziche M, Morbidelli L, Choudhuri R, Zhang HT, Donnini S, Granger HJ, Bicknell R. Nitric oxide synthase lies downstream from vascular endothelial growth factor-induced but not basic fibroblast growth factorinduced angiogenesis. J Clin Invest 99: 2625-2634, 1997.

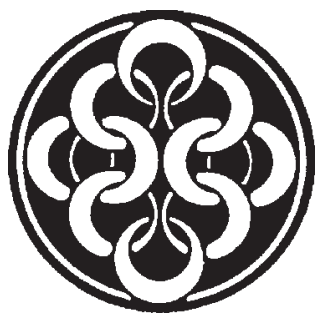

